\title{
KEANDALAN INFORMASI LAPORAN KEUANGAN DAERAH BERBASIS AKRUAL: Kajian Pengelolaan Aset Tetap Daerah Kabupaten Sampang
}

\author{
Karnanto Priyono \\ BPK (Badan Pemeriksa Keuangan) Papua \\ No. Telp081233095854
}

\section{ABSTRACT}

Reliability of financial statements required for financial statements useful to users. therefore fixed asets must be managed properly in order to produce reliable information in the financial statements. The study was conducted to test the reliability of the asets informations in Sampang County Government. Whether the reliability of information in the financial statements are free of misleadingmaterial mistake, fairly presenting any facts, and can be verified. Fixed aset management area is an effort to improve theefficiency, effectiveness and creating added value in managing the asets. TheAsets management are based on the principle of functional management, legalcertainty, transparency and openness, efficiency,accountability, and assurance of value.This study is a qualitative research with Post-positivist research paradigm with a case studyapproach. The research object is the information content of fixed asetsin the Financial report of Goverment District of Sampang . Data analysis was performed withdata reduction, understanding and interpretation. The results suggest that the management of goods / asets owned in the district has ot performed adequately, resulting in unreliable presentation of asets informations. It is recommended that the district goverment should draw up the accounting policies about the depreciation of fixed asets, improve the coordination of the entire workunits (SKPD), andcomplete the value reconciliation between Accounting and Reporting Departmentand Aset Management Department. Research sites in only one local government and is limited to fixed aset management area, the research does not conduct studies on all accounts.

Keywords: Reliability, Management, Fixed Regional'sAsets

\section{ABSTRAKSI}


Keandalan penyajian laporan keuangan diperlukan agar laporan keuangan bermanfaat bagi pengguna. Untuk itu aset tetap harus dikelola dengan baik agar menghasilkan informasi yang andal dalam laporan keuangan daerah.Penelitian ini dilakukan untuk menguji keandalan informasi aset tetap daerah pada Pemerintah Kabupaten Sampang. Keandalan informasi dalam laporan keuangan diartikan bebas dari pengertian yang menyesatkan dan kesalahan material, menyajikan setiap fakta secara jujur, serta dapat diverifikasi.Pengelolaan aset tetap daerah merupakan upaya meningkatkan efisiensi, efektifitas dan menciptakan nilai tambah dalam mengelola aset.Pengelolaan dilaksanakan berdasarkan asas fungsional, kepastian hukum, transparansi dan keterbukaan, efisiensi, akuntabilitas, dan kepastian nilai.Penelitian ini merupakan penelitian kualitatif dengan paradigma penelitian Post-positivisme dengan pendekatan studi kasus.Obyek penelitian adalah kandungan informasi aset tetap daerah pada Laporan Keuangan Pemerintah Daerah Kabupaten Sampang. Analisis data dilakukan dengan data reduction, understanding dan interpretation. Hasil penelitian menunjukkan pengelolaan Barang/aset Milik daerah pada Kabupaten Sampang belum dilaksanakan secara memadai sehingga menghasilkan penyajian informasi aset tetap daerah yang belum andal. Untuk itu disarankan segera disusun kebijakan akuntansi yang mengatur tentang penyusutan aset tetap, meningkatkan koordinasi pada seluruh Satuan Kerja Perangkat (SKPD), dan menuntaskan rekonsiliasi antara Bidang Akuntansi dan Pelaporan dengan Bidang Pengelolaan Aset. Situs penelitian hanya pada satu pemerintah daerah dan hanya terbatas pada pengelolaan aset tetap daerah, tidak melakukan kajian pada semua akun.

Keywords : Keandalan, Pengelolaan, Aset Tetap Daerah

\section{PENDAHULUAN}

Dewasa ini kebutuhan atas informasi keuangan yang informatif semakin meningkat, baik di sektor privat maupun di sektor publik. Untuk itu penyajian laporan keuangan yang andal diperlukan agar laporan keuangan bermanfaat bagi pengguna. Akuntansi adalah sistem informasiyang memberi informasi melalui angka-angka kuantitatif. Informasi ini dapat menjadi dasar dalam proses pengambilan keputusan. Pengambilan keputusan akan semakin tepat jika informasi yang disajikan akurat dan juga relevan. Tanpa akurasi dan relevansi, dikhawatirkan keputusan yang diambil akan meleset (Harahap, 2007).

Di sektor publik, salah satu masalah krusial yang dihadapi pemerintah, baik pemerintah pusat maupun pemerintah daerah, dalam menyajikan Laporan Keuangan andal adalah berkaitan dengan penyajian akun Aset Tetap di Neraca Daerah.Untuk mengetahui bagaimana cara menentukan nilai aset tetap maka harus 
diketahui pula bagaimana tatacara administrasiaset tetap, selanjutnya menentukan bagaimana sistem dan prosedur pengelolaan aset tetap yang dapat digunakan untuk menilai aset tetap dalam rangka menyusun neraca daerah. Barang milik daerah (BMD)/aset daerah sebagai salah satu unsur penting dalam penyelenggaraan pemerintahan dan pelayanan masyarakat harus dikelola dengan baik dan benar. Oleh karena itu penyajian barang milik daerah dalam laporan keuangan harus transparan dan akuntabel, sehingga pengelolaannya dapat dipertanggungjawabkan kepada masyarakat untuk mewujudkan prinsip good governance di sektor publik.

Selama penerapan SAP berbasis Kas menuju Akrual berdasarkan Peraturan Pemerintah Nomor 24 tahun 2005, sebagian besar Pemerintah Kota/Kabupaten di Indonesia belum mampu melakukan pengelolaan Aset Tetap Daerah dengan baik. Dari 499 Laporan Keuangan Pemerintah Daerah tahun anggaran 2009 yang diaudit oleh BPK pada tahun 2010, hanya 15 Pemerintah Daerah (atau 3\%) yang mampu memperoleh opini Wajar Tanpa Pengecualian (WTP). Opini Tidak Memberikan Pendapat dan Tidak Wajar diberikan oleh BPK sebagian besar disebabkan kelemahan sistem pengendalian intern (SPI) atas laporan keuangan pemerintah daerah. Kelemahan SPI yang umum terjadi terutama dalam pengendalian aset tetap seperti nilai aset tetap tidak dikapitalisasi dengan biayabiaya yang telah dikeluarkan, perbedaan pencatatan antara saldo aset tetap pada neraca dengan dokumen sumber dan penyajian aset tetap tidak didasarkan hasil inventarisasi dan penilaian. Hal-hal tersebut berpengaruh terhadap saldo aset tetap sehingga mempengaruhi kewajaran laporan keuangan (Akram, 2011).

Di Provinsi Jawa Timur,berdasarkan Laporan Hasil Pemeriksaan (LHP) Badan Pemeriksa Keuangan RI (BPK RI) Perwakilan Provinsi Jawa Timur Tahun Anggaran 2007 s.d 2010, dari 39 entitas pemeriksaan hanya terdapat 6 entitas yang mendapat opini Wajar Tanpa Pengecualian atas Laporan Keuangan Daerah.

Sebagaimana dengan daerah lain di Jawa Timur, Pemerintah Kabupaten Sampang belum mengelola aset tetap yang dimiliki dengan baik. Berdasarkan Laporan Hasil Pemeriksaan (LHP) atas Laporan Keuangan Daerah pada Kabupaten Sampang oleh BPKRI Perwakilan Propinsi Jawa Timur antara Tahun Anggaran 2007 - 2010, diketahui bahwa kelemahan penyajian aset tetap menjadi 
salah satu penyebab pengecualian dalam pemberian opini atas penyajian laporan keuangan daerah.Temuan BPKRI Perwakilan Propinsi Jawa Timur yang menjadi pengecualian dalam pemeriksaan atas LKPD Kabupaten Sampang berkaitan dengan pengelolaan aset tetap dapat dilihat pada tabel berikut.

Tabel 1. Temuan BPKRI yang menjadi pengecualian dalam pemberian opini atas LKPD Kabupaten Sampang berkaitan dengan pengelolaan aset tetap

\begin{tabular}{|c|c|c|}
\hline No. & $\begin{array}{c}\text { Tahun } \\
\text { Anggaran }\end{array}$ & Pengecualian Berkaitan Dengan Pengelolaan Aset \\
\hline 1. & 2007 & $\begin{array}{l}\text { - Terdapat Belanja Modal sebesar Rp1.502.244.900,00 yang dicatat } \\
\text { dalam Belanja Barang dan Jasa dalam Laporan Realisasi Anggaran. }\end{array}$ \\
\hline 2. & 2008 & $\begin{array}{l}\text { - Terdapat kesalahan penganggaran dan realisasi belanja modal pada } \\
\text { belanja bahan bangunan sebesar Rp817.436.000,00 } \\
\text { - Terdapat kekurangan volume pekerjaan sebesar Rp107.000.379,73 } \\
\text { pada lima Satuan Kerja Perangkat Daerah (SKPD) } \\
\text { - Terdapat aset pemda berupa tanah dengan nilai perolehan } \\
\text { Rp3.543.562.072,00 tidak ada bukti kepemilikan dan dikuasai oleh } \\
\text { penduduk } \\
\text { - Belanja Modal Tanah untuk Pembangunan Stadion Olahraga Sebesar } \\
\text { Rp3.675.000.000,00 Tidak Didukung Dokumen yang Memadai } \\
\text { - Terdapat item pekerjaan yang tidak dilaksanakan dan kekurangan } \\
\text { volume pekerjaan senilai minimal Rp2.454.703.379,16 pada } \\
\text { pembangunan pasar Srimangunan Tahap III }\end{array}$ \\
\hline 3. & 2009 & $\begin{array}{l}\text { - Pada akun Aset Tetap dengan nilai total sebesar } \\
\text { Rp2.565.540.628.944,46 diketahui terdapat perbedaan nilai antara } \\
\text { Bidang Aset dengan Bidang Akuntansi dan Pembukuan } \\
\text { - Pada Akun Belanja Modal sebesar Rp257.821.922.964,00 diketahui } \\
\text { terdapat pengeluaran sebesar Rp11.602.036.000,00 yang dihibahkan } \\
\text { kepada kelompok masyarakat }\end{array}$ \\
\hline 4. & 2010 & $\begin{array}{l}\text { - Terdapat perbedaan antara saldo neraca dengan hasil klarifikasi data } \\
\text { pendukung pada SKPD untuk aset tetap tanah sebesar Rp25,48 miliar, } \\
\text { peralatan dan mesin sebesar Rp132,92 miliar, gedung dan bangunan } \\
\text { sebesar Rp263,90 miliar, dan jalan irigasi dan jaringan sebesar } \\
\text { Rp406,46 miliar. }\end{array}$ \\
\hline
\end{tabular}

Sumber : LHP BPK RI Perwakilan Propinsi Jawa Timur

Dari tabel di atas dapat dilihat bahwa sampai dengan Tahun Anggaran 2010, permasalahan pengelolaan aset tetap di Kabupaten Sampang terjadi sejak proses perencanaan sampai dengan pelaporan di Neraca Daerah. Keandalan penyajian aset tetap di Neraca Daerah Pemerintah Kabupaten Sampang masih perlu dipertanyakan mengingat bahwa sampai saat ini masih terdapat perbedaan pencatatan nilai aset tetap oleh Bidang Aset dan Bidang Akuntansi.

Sebagaimana diketahui bersama, usaha peningkatan kualitas laporan keuangan pada sektor publik telah dilakukan oleh Pemerintah Indonesiadengandilaksanakannya reformasi bidang akuntansi. Salah satu reformasi yang dilakukan adalah keharusan penerapan akuntansi berbasis akrual pada setiap instansi pemerintahan, baik pemerintah pusat maupun pemerintahan 
daerah, yang dimulai tahun anggaran 2008. Perkembangan terakhir, telah terbit Peraturan Pemerintah Nomor 71 tahun 2010 tentang SAP berbasis Akrual sebagai pengganti PP 24 tahun 2005.Dengan diberlakukannya SAP Berbasis Akrual, peraturan pelaksanaan dan sistem akuntansi akan berubah, demikian pula dengan kapasitas dan kemampuan SDM harus ditingkatkan, karena SAP Berbasis Akrual dapat memberi informasi keuangan yang lebih baik, meskipun implementasinya lebih rumit dibanding SAP Berbasis Kas Menuju Akrual.

Menurut Pratama (2007) dalam Analisis Faktor-Faktor Yang Menyulitkan Penerapan Akuntansi Akrual dan Pengaruhnya Terhadap Kualitas Informasi Akuntansi Di Pemerintahan Indonesia, reformasi pengelolaan keuangan negara telah memunculkan konsep akuntansi akrual di pemerintahan, dimana faktor kesulitan penerapan di pemerintahan adalah Kesiapan SDM, Praktek Keuangan, dan Peraturan Perundang-Undangan. Ketiga faktor ini mempengaruhi kualitas informasi dari akuntansi pemerintahan.

Oleh karena itu, dalam rangka menguji kualitas informasi keuangan, khususnya dalampenyajian aset tetap dalam laporan keuangan daerah, maka penelitian ini akan mencoba memahami keandalan informasi laporan keuangan daerah berbasis akrual: kajian pengelolaan aset tetap daerah pada Pemerintah Kabupaten Sampang

\section{KAJIAN PUSTAKA}

Kerangka teori dalam penelitian kualitatif bukan untuk diuji tetapi sekedar untuk membantu memahami atau menafsirkan realitas sosial yang akan diteliti. Posisi teori hanya dimanfaatkan untuk membantu memahami atau menafsirkan gejala sosial yang ada. Teori yang digunakan untuk membahas penelitian adalah:

\section{Definisi Aset/Barang Milik Daerah}

Menurut Peraturan Dalam Negeri Nomor 17 Tahun 2007 tentang Pedoman Teknis Pengelolaan Barang Milik Daerah, yang dimaksud barang milik daerah adalah semua barang yang dibeli atau diperoleh atas beban Anggaran Pendapatan dan Belanja Daerah atau perolehan lainnya yang sah meliputi:Barang yang diperoleh dari hibah/sumbangan atau yang sejenis;Barang yang diperoleh sebagai pelaksanaan dari perjanjian/kontrak;Barang yang diperoleh berdasarkan ketentuan 
undang-undangatauBarang yang diperoleh berdasarkan putusan pengadilan yang telah memperoleh kekuatan hukum tetap.

Selanjutnya, barang milik daerah dibedakan menjadi dua jenis, yaitu barang inventaris dan barang pakai habis.

\section{Aset Tetap}

Definisi aset tetap menurut Pernyataan Standar Akuntansi Pemerintahan 07 adalah aset berwujud yang mempunyai masa manfaat lebih dari 12 (dua belas) bulan untuk digunakan dalam kegiatan pemerintah atau dimanfaatkan oleh masyarakat umum.

Standar Akuntansi Pemerintahan dan Peraturan Dalam Negeri Nomor 17 tahun 2007 mengklasifikasikan Aset Tetap dan Barang Inventaris sebagai berikut:Tanah;Peralatan dan Mesin;Gedung dan Bangunan;Jalan, Irigasi, dan Jaringan;Aset Tetap Lainnya; danKonstruksi dalam Pengerjaan.

Menurut Pemerintah Kabupaten Sampang yang dituangkan dalam Peraturan Bupati Nomor 26 Tahun 2009 tentang Kebijakan Akuntansi Kabupaten Sampang, aset adalah sumber daya ekonomi yang dikuasai dan/atau dimiliki oleh pemerintah daerah sebagai akibat dari peristiwa masa lalu dan dari mana manfaat ekonomi dan/atau sosial di masa depan diharapkan dapat diperoleh, baik oleh pemerintah daerah maupun masyarakat, serta dapat diukur dalam satuan uang, termasuk sumber daya nonkeuangan yang diperlukan untuk penyediaan jasa bagi masyarakat umum dan sumber-sumber daya yang dipelihara karena alasan sejarah dan budaya. Sedangkan definisi aset tetap adalah aset berwujud yang mempunyai masa manfaat lebih dari 12 (dua belas) bulan untuk digunakan dalam kegiatan pemerintah atau dimanfaatkan oleh masyarakat umum.

\section{Pengelolaan Aset Daerah}

Perubahan paradigma baru pengelolaan barang milik negara/aset negara yang ditandai dengan keluarkannya Peraturan Pemerintah Nomor 6 Tahun 2006tentang Pengelolaan Barang Milik Negara/Daerah, telah memunculkan optimisme baru best practices dalam penataan dan pengelolaan aset daerah yang lebih tertib, akuntabel, dan transparan kedepannya. Pengelolaan aset negara dalam pengertian yang dimaksud dalam Pasal 1 Ayat (1) dan Ayat (2) PP No. 6/2006 tidak sekedar administratif semata, tetapi lebih maju berfikir dalam menangani 
aset negara, dengan bagaimana meningkatkan efisiensi, efektifitas dan menciptakan nilai tambah dalam mengelola aset.

\section{Keandalan}

Keandalan merupakan bagian dari Karakteristik Kualitatif Laporan Keuangan. Informasi mungkin relevan, tetapi jika hakikat atau penyajiannya tidak dapat diandalkan maka penggunaan informasi tersebut secara potensial dapat menyesatkan. Informasi yang andal memenuhi karakteristikPenyajian Jujur, Dapat Diverifikasi (verifiability) dan Netralitas.

\section{Penyusutan Aset Tetap}

Penyajian informasi Aset Tetap yang andal, tidak lepas dari kebijakan penyusutan. Arti penting penyusutan Aset Tetap juga diungkapkan dalam Buletin Teknis yang diterbitkan Komite Standar Akuntansi Pemerintahan Nomor 05 tentang Akuntansi Penyusutan. Salah satu informasi yang sangat dibutuhkan dalam pengambilan keputusan yang terkait dalam pengelolaan aset tetap adalah informasi mengenai nilai wajar aset. Dalam rangka penyajian wajar atas nilai aset tetap tersebut, pemerintah daerah dapat melakukannya melalui penetapan kebijakan penyusutan.

\section{Laporan Keuangan Pemerintah Daerah (LKPD)}

Pernyataan Standar Akuntansi Pemerintahan (PSAP) No. 1 paragraf 9 menyatakan bahwa laporan keuangan merupakan laporan yang terstruktur mengenai posisi keuangan dan transaksi-transaksi yang dilakukan oleh suatu entitas pelaporan. Tujuan umum laporan keuangan adalah menyajikan informasi mengenai posisi keuangan, realisasi anggaran, arus kas, dan kinerja keuangan suatu entitas pelaporan yang bermanfaat bagi para pengguna dalam membuat dan mengevaluasi keputusan mengenai alokasi sumber daya.

\section{Basis Akrual dalam Standar Akuntansi Pemerintahan menurut Peraturan Pemerintah Nomor 71 Tahun 2010}

Peraturan Pemerintah Nomor 71 Tahun 2010 tentang Standar Akuntansi Pemerintahan pada pasal 4 ayat (1) menyebutkan bahwa Pemerintah menerapkan SAP Berbasis Akrual. Laporan keuangan harus mengungkapkan untuk masing masing jenis aset tetap sebagai berikut:Dasar penilaian yang digunakan untuk menentukan nilai tercatat(carrying amount);Rekonsiliasi jumlah tercatat pada 
awal dan akhir periode;Informasi penyusutan;Eksistensi dan batasan hak milik atas aset tetap;Kebijakan akuntansi untuk kapitalisasi yang berkaitan dengan aset tetap;Jumlah pengeluaran pada pos aset tetap dalam konstruksi; danJumlah komitmen untuk akuisisi aset tetap.

Jika aset tetap dicatat pada jumlah yang dinilai kembali, maka hal-hal berikut harus diungkapkan:Dasar peraturan untuk menilai kembali aset tetap;Tanggal efektif penilaian kembali;Jika ada, nama penilai independen;Hakikat setiap petunjuk yang digunakan untuk menentukan biaya pengganti;Nilai tercatat setiap jenis aset tetap.

Aset bersejarah diungkapkan secara rinci, antara lain nama,jenis, kondisi dan lokasi aset dimaksud.

\section{METODE PENELITIAN}

\section{Paradigma Penelitian}

Penelitian ini merupakan penelitian kualitatif dengan paradigma penelitian Post-positivisme dengan pendekatan studi kasus. Dengan paradigma ini peneliti melakukan penyimpulan secara deduktif dan logis dengan memberikan perhatian pada pengumpulan data empiris dan berdasarkan pada teori yang ada. (Creswell, 2007)

\section{Informan dan Pengumpulan Informasi}

Pemilihan para informan dalam penelitian dilakukan secara sengaja(purposive), berdasarkan kriteria yang dijelaskan oleh Bungin (2003: 5455), antara lain: Pertama, informan merupakan individu yang telah cukup lama dan intensif menyatu dengan kegiatan atau medan aktivitas yang menjadi sasaran penelitian.Subyek tidak hanya sekedar tahu dan dapat memberikan informasi, tetapi juga telah menghayati secara sungguh-sungguh sebagai akibat dari keterlibatannya yang cukup lama dengan lingkungan atau kegiatan yang bersangkutan. Kedua, informan masih terlibat secara aktif pada lingkungan atau kegiatan yang menjadi fokus penelitian.

Berdasarkan kriteria-kriteria tersebut, individu-individu yang menjadi key informandalam penelitian ini terdiri atas:Pemeriksa pada Badan Pemeriksa Keuangan RI Perwakilan Provinsi Jawa Timur;Pegawai Pemerintah Daerah yang menempati posisi sebagai Kepala Bidang Akuntansi dan Pelaporan;Pegawai 
Pemerintah Daerah yang menempati posisi sebagaiKepala Bidang Pengelolaan Aset;

\section{Satuan Kajian}

Sebagai bagian dari informasi yang disajikan dalam laporan keuangan, penyajian informasi aset tetap daerah harus mempunyai tingkat keandalan informasi yang menjadi salah satu karakteristik kualitatif laporan keuangan yang merupakan prasyaratnormatif yang diperlukan agar laporan keuangan pemerintah dapat memenuhi kualitas yang dikehendaki. Pengelolaan Aset Tetap Daerah yang baik oleh Pemerintah Kabupaten Sampang merupakan salah satu indikator pemenuhan kualitas informasi mengenai aset tetap daerah.

Aset tetap daerah sebagai salah satu unsur penting dalam penyelenggaraan pemerintahan dan pelayanan masyarakat harus dikelola dengan baik dan benar, yang pada gilirannya dapat mewujudkan pengelolaan aset tetap daerah dengan memperhatikan azas-azas sebagai berikut. (Permendagri 17 Tahun 2007, hal: 28): Azas fungsional;Azas kepastian hukum;Azas efisiensi;Azas akuntabilitas;Azas kepastian nilai.

Pengelolaan barang milik daerah yang baik dan benar pada akhirnya akan menghasilkan informasi yang andal sebagaimana dapat dilihat dalam gambar berikut.

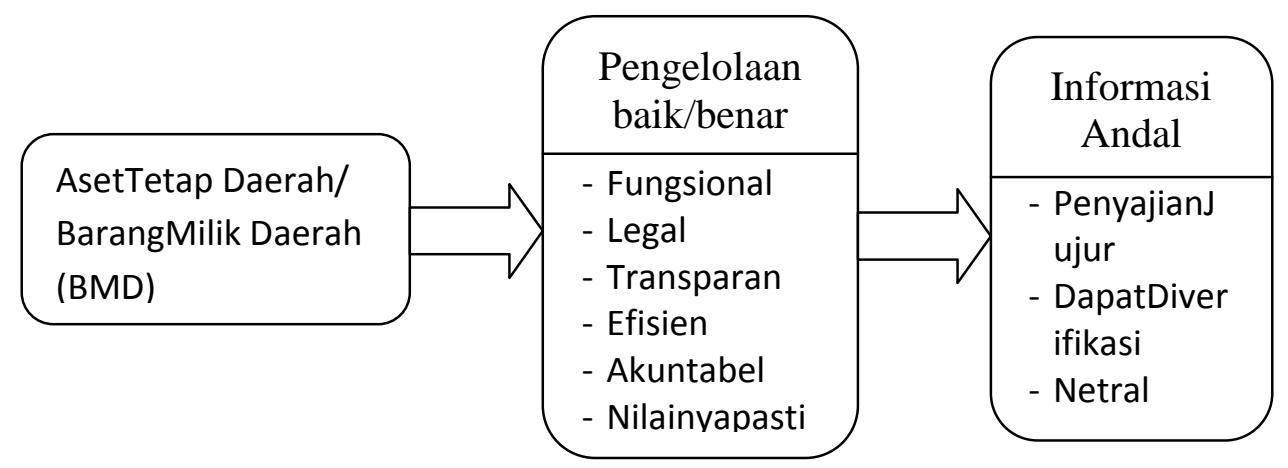

Kajian atas pengelolaan aset daerah yang baik dan benar dinilai dari aspekaspek pengelolaan untuk selanjutnya dihubungkan dengan keandalan informasi mengenai aset daerah tersebut.

Kajian keandalan atas informasi aset tetap daerah dilakukan dengan menilai apakah informasisudah disajikan dengan jujur, dapat diverifikasi (verifiability) 
dan memenuhi unsur netralitas, yaitu informasi diarahkan pada kebutuhan umum dan tidak berpihak pada kebutuhan pihak tertentu.

\section{Obyek Penelitian}

Obyek penelitian adalah kandungan informasi aset tetap daerah pada Laporan Keuangan Pemerintah DaerahKabupaten Sampang,Kartu Inventaris Barang dan Laporan Hasil Pemeriksaan Badan Pemeriksa Keuangan RI atas Laporan Keuangan Daerah Pemerintah Kabupaten Sampang serta pemahaman key informan mengenai pengelolaan aset tetap daerah.

\section{Pengumpulan Data}

Pengumpulan data dilakukan melalui wawancara yang tidak terstruktur, tidak terjadwal, dan dilakukan sedemikian rupa sehingga dalam memberikan informasi, para informan tidak cenderung mengolah atau mempersiapkan informasi tersebut lebih dulu, serta dapat memberikan penjelasan apa adanya. Dalam observasi juga dapat dipergunakan data hasil pekerjaan key informan sebagai bentuk representasi dari pemahaman mereka yaitu Laporan Keuangan Pemerintah Daerah (LKPD) dan Kartu Inventaris Barang (KIB).

\section{Teknik Analisa Data}

Pada penelitian naturalistik menurut Moleong (1988), analisis data pada umumnya mengandung tiga kegiatan yang saling terkait yaitu a) kegiatan mereduksi data, b) menampilkan data, dan c) melakukan verifikasi untuk membuat kesimpulan. Data yang telah diklasifikasi kemudian direkonstruksi maknanya. Rekonstruksi makna diarahkan untuk menangkap pemahaman yang ada di kalangan penyelenggara akuntansi pemerintahan.

Chariri (2009) menyatakan dalam penelitian kualitatif, tidak ada pendekatan tunggal dalam analisis data. Pemilihan metode sangat tergantung pada research questions (Baxter and Chua, 1998); research strategies dan theoretical framework (Glaser and Strauss, 1967). Untuk melakukan analisis, peneliti perlu menangkap, mencatat, menginterpretasikan dan menyajikan informasi. Satu hal yang perlu diperhatikan oleh peneliti adalah dalam penelitian kualitatif, analisis data tidak dapat dipisahkan dari data collection. Oleh karena itu, ketika data mulai terkumpul dari interviews, observation dan archival sources, analisis data harus segera dilakukan untuk menentukan pengumpulan data berikutnya. 


\section{PEMBAHASAN}

\section{Pengelolaan Aset Tetap Daerah oleh Pemerintah Kabupaten Sampang pada tahap perencanaan, pelaksanaan dan pelaporan}

Mulai Tahun Anggaran 2009, pengelolaan aset daerah di lingkungan Pemerintah Kabupaten Sampang menjadi tanggung jawab Bidang Perlengkapan dan Aset. Berdasarkan Peraturan Bupati Nomor 52 Tahun 2008 tentang Tugas, Fungsi dan Tata Kerja Dinas Pendapatan, Pengelolaan Keuangan dan Aset Kabupaten Sampang disebutkan bahwa Bidang Pengelolaan Aset mempunyai tugas menyusun perencanaan dan pengendalian, pemanfaatan dan inventarisasi barang milik daerah sesuai ketentuan yang berlaku.

Penelitian atas pengelolaan aset tetap di Neraca Daerah Kabupaten Sampang difokuskan pada tahap perencanaan, pelaksanaan dan pelaporan.

\section{Tahap Perencanaan}

Dalam Peraturan Daerah Nomor 24 Tahun 2008 tentang Pengelolaan Barang Milik Daerah Kabupaten Sampang, tahap perencanaan dalam pengelolaan barang/aset milik daerah diatur sebagai berikut.

1. Perencanaan kebutuhan barang milik daerah disusun dalam rencana kerja dan anggaran satuan kerja perangkat daerah setelah memperhatikan ketersediaan barang milik daerah yang ada;

2. Perencanaan kebutuhan pemeliharaan barang milik daerah disusun dalam rencana kerja dan anggaran satuan kerja perangkat daerah dengan memperhatikan data barang yang ada dalam pemakaian;

3. Perencanaan kebutuhan dan pemeliharaan barang milik daerah berpedoman pada standarisasi sarana dan prasarana kerja pemerintahan daerah yang ditetapkan dengan Peraturan Kepala Daerah dan standar harga yang ditetapkan dengan Keputusan Kepala Daerah;

4. Peraturan Kepala Daerah dan Keputusan Kepala Daerah tersebut dijadikan acuan dalam menyusun Rencana Kebutuhan Barang Milik Daerah (RKBMD) dan Rencana Kebutuhan Pemeliharaan Barang Milik Daerah (RKPBMD);

5. Rencana Kebutuhan Barang Milik Daerah dan Rencana Kebutuhan Pemeliharaan Barang Milik Daerah tersebut sebagai dasar penyusunan Rencana Kerja dan Anggaran (RKA) masing-masing satuan kerja perangkat daerah sebagai bahan penyusunan Rencana APBD.

Hasil penelitian menunjukkan bahwa dalam pelaksanaannya terdapat tahaptahap perencanaan yang dilewatkan dalam pengelolaan barang milik daerah di Kabupaten Sampang. Hal ini sebagaimana disampaikan oleh Kabid Akuntansi dan Pelaporan dalam petikan wawancara berikut. 
“....tidak adanya rencana kebutuhan barang daerah mengakibatkan pengadaan barang/aset daerah tidak mendukung upaya pencapaian target kinerja pada satuan kerja. Tanpa Rencana Kebutuhan Barang (RKB), suatu SKPD tidak dapat memenuhi jumlah kebutuhan barang sesuai dengan kebutuhan unit kerjanya. Selama ini praktek yang terjadi, jumlah kebutuhan barang menyesuaikan dengan anggaran yang disusun dalam RKA."

Kegiatan perencanaan kebutuhan barang tidak hanya berkaitan dengan pemenuhan kebutuhan barang/aset daerah, tetapi berkaitan juga dengan pembebanan pengeluaran dalam mata anggaran yang tepat. Permasalahan terkait penganggaran dan realisasi belanja barang/aset daerah pada Pemerintah Kabupaten Sampang diketahui terdapat kesalahan penganggaran dalam kegiatan pengadaan barang/aset daerah. Hasil pemeriksaan atasbukti pertanggungjawaban Belanja Langsung diketahui bahwa penganggaran belanja hibah dan belanja modal belum sesuai Standar Akuntansi Pemerintahan (SAP) sebesar Rp100.000.000,00 dan Rp4.680.059.320,00.

Menurut pemeriksa BPK RIpenganggaran belanja hibah tersebut belum sesuai Standar Akuntansi Pemerintahan (SAP),ketidaksesuaian hal tersebut seperti diungkapkan dalam petikan wawancara berikut.

“.....seharusnya atas realisasi belanja hibah tersebut lebih tepat apabila dianggarkan pada belanja barang dan jasa pada SKPD Sekretariat Dewan Pengurus KORPRI Kabupaten Sampang.”

Terjadinya kesalahan penganggaran tersebut menunjukkan bahwa perencanaan dalam pengelolaan barang milik daerah belum dilaksanakan dengan baik.

Di samping itu terdapat pula penganggaran dan realisasi Belanja Bantuan Dicatat sebagai Belanja Modal sebesar Rp4.680.059.320,00 pada Dinas Pendidikan dalam pelaksanaan DAK pada TA 2011 dan dana pendampingnya (DAU) diketahui bahwa pencairan dan penggunaan DAK dan pendampingnya (DAU) bagi sekolah swasta sebesar Rp4.680.059.320,00 dibebankan sebagai belanja modal pada Dinas Pendidikan. Realisasi belanja modal DAK dan pendampingnya (DAU) bagi sekolah swasta seharusnya dianggarkan pada belanja hibah. 
Atas permasalahan tersebut, Kepala Dinas Pendapatan Pengelolaan Keuangan dan Aset menyatakan bahwa:

“...belanja hibah kepada Dewan Pengurus KORPRI dianggarkan pada saat penyusunan APBD Tahun Anggaran 2011, pada saat itu SKPD Sekretariat Dewan Pengurus KORPRI belum terbentuk. Sedangkan terhadap penganggaran dan realisasi belanja modal yang bersumber dari DAK untuk sekolah swasta, Dinas Pendidikan belum bisa memisahkan pembebanan biaya DAK untuk sekolah negeri dan swasta pada saat penyusunan anggaran. Menambahkan penjelasan dari Kepala Dispendaloka, Kepala Dinas Pendidikan menyatakan pada waktu penyusunan RKA sampai dengan DPA, Juknis penggunaan dana DAK bidang Pendidikan belum diterima, sehingga belum bisa menentukan alokasi untuk sekolah negeri dan swasta."

\section{Tahap Pelaksanaan}

Berdasarkan Peraturan Daerah Nomor 24 Tahun 2008 tentang Pengelolaan Barang Milik Daerah Kabupaten Sampang, pelaksanaan pengelolaan barang/aset daerah dapat digolongkan dalam kegiatan Pengadaan Barang, Penyimpanan, Penggunaan dan Pemeliharaan, Inventarisasi, Perubahan Status, Pemanfaatan, Pengamanan, serta Pembinaan, Pengendalian dan Pengawasan. Pengelolaan barang/aset milik daerah dilaksanakan oleh Kepala Daerah dan seluruh perangkat daerah sebagai unsur penyelenggara pemerintah daerah.

Peneliti menemukan permasalahan dalam pelaksanaan pengelolaan barang/aset milik daerah terutama dalam hal pengadministrasian barang/aset milik daerah. Hal ini dapat dilihat dari adanya perbedaan antara saldo aset tetap daerah yang tercatat dalam Kartu Inventaris Barang (KIB) dengan saldo aset tetap daerah dalam pembukuan akuntansi. Di samping itu berdasarkan wawancara dengan pemeriksa BPK RI diketahui bahwa terdapat perbedaan pengkodean jenis barang, sehingga dapat menimbulkan kemungkinanan barang hilang karena tidak dapat ditelusuri.

Permasalahan lain dalam pengelolaan aset tetap adalah terkait dengan pengalihan aset tetap dari satu SKPD ke SKPD lainnya. Pengalihan penggunaan aset tetap antar SKPD belum dilaksanakan dengan tertib sehingga pada saat pelaksanaan inventarisasi aset daerah, Bidang Pengelolaan Aset mengalami kesulitan dalam menelusuri keberadaan sejumlah aset.

\section{Tahap Pelaporan}


Permasalahan dalam pelaporan barang/aset daerah pertama kali teridentifikasi pada tahun 2010. Berdasarkan Laporan Hasil Pemeriksaan Badan Pemeriksa Keuangan (BPK) atas pemeriksaan terhadap Laporan Keuangan Kabupaten Sampang Tahun Anggaran 2009 disebutkan bahwa penyajian aset tetap di neraca daerah tidak dapat diyakini kewajarannya. Ketidakwajaran tersebut dinilai dari adanya perbedaan pembukuan aset tetap antara Bidang Akuntansi dan Pelaporan dengan Bidang Pengelolaan Aset. Dalam Neraca Daerah per 31 Desember 2009, Aset Tetap yang dimiliki oleh Kabupaten Sampang disajikan sebesar Rp2.568.282.846.784,77. Sedangkan menurut bidang pengelola aset, nilai tersebut adalah Rp1.332.398.744.686,09, sehingga nilai aset di neraca lebih tinggi sebesar Rp1.235.884.102.098,68 dengan rincian perbedaan sebagai berikut.

- Peralatan dan Mesin $\quad$ Rp 354.406.986.938,63

- Gedung dan Bangunan Rp 265.282.775.050,72

- Jalan, Irigasi dan Jaringan $\underline{R p} \quad 616.194 .340 .109,33$

Rp 1.235.884.102.098,68

Penjelasan Kepala Bidang Akuntansi dan Pelaporan pada Dinas Pendapatan, Pengelolaan Keuangan dan Aset (Dispendaloka) menyebutkan bahwa perbedaan tersebut terjadi karena terdapat perbedaan data yang dimiliki oleh bidang akuntansi dan pelaporan dengan bagian pengelolaan aset.

Secara umum hal-hal yang menyebabkan timbulnya permasalahan pelaporan dalam pengelolaan aset daerah di lingkungan Pemerintah Kabupaten Sampang adalah sebagai berikut.

a. Neraca awal tidak dapat diyakini kewajaran penyajiannya;

b. Laporan Keuangan Kabupaten Sampang bukan merupakan hasil konsolidasi dari seluruh Neraca SKPD;

c. Penyajian aset lainnya tidak tepat;

d. Penghapusan aset tetap belum optimal.

Upaya perbaikan yang dilakukan oleh Pemerintah Kabupaten Sampang dengan adanya permasalahan perbedaan pembukuan aset tetap tersebut adalah:

a. Terhadap aset tetap yang harga perolehannya sudah didapat/dokumen kontrak sudah diketemukan akan dilakukan validasi kembali terhadap buku inventaris tahun 2008.

b. Terhadap aset tetap yang harga perolehannya sudah tidak diketemukan/dokumen kontrak sudah tidak ada, akan dibuatkan Surat Keputusan Bupati tentang Nilai Wajar aset pada saat pengadaan dan kegiatan tersebut telah dianggarkan pada tahun 2011. Dinas Pendapatan, Pengelolaan Keuangan dan Aset Kabupaten Sampang Program Peningkatan 
Pengembangan Pengelolaan Keuangan Daerah Kegiatan Peningkatan Manajemen aset / barang daerah.

c. Terhadap aset tetap yang sudah dihapus/lelang/rusak/dihibahkan akan dilakukan proses penghapusan sesuai dengan ketentuan yang berlaku.

d. Tim Fokus Group Pendampingan Penatausahaan Aset Daerah akan melakukan kembali validasi aset tetap dengan pihak SKPD berdasarkan Buku Inventaris Tahun 2004, Data Perhitungan APBD tahun 2004 - 2010 dan dokumen pendukung aset tetap.

e. Akanmelakukanrekonsiliasi antara Bendahara Pengeluaran dengan Bendahara Barang.

Keandalan penyajian aset tetap pemerintah daerah pada Pemerintah

\section{Kabupaten Sampang}

Pengelolaan barang/aset milik daerah akan menentukan kualitas keandalan penyajian informasi barang/aset tetap dalam laporan keuangan Pemerintah Daerah. Untuk menilai baik buruknya pengelolaan aset tetap daerah dengan memperhatikan azas-azas sebagai berikut.

a. Azas fungsional, yaitu pengambilan keputusan dan pemecahan masalah di bidang pengelolaan barang milik daerah dilaksanakan oleh kuasa pengguna barang, pengguna barang, pengelola barang dan Kepala Daerah sesuai fungsi, wewenang dan tanggungjawab masing-masing. Di lingkungan Pemerintah Kabupaten Sampang, meskipun tanggungjawab dan wewenang masingmasing pejabat pengelola barang/aset milik daerah telah diatur dalam Peraturan Daerah Nomor 24 Tahun 2008 tentang Pengelolaan Barang Milik Daerah Kabupaten Sampang, namun dalam prakteknya beberapa fungsi tidak berjalan dengan baik. Sebagai contoh fungsi koordinasi dalam pelaksanaan inventarisasi barang/aset milik daerah yang melekat pada Sekretaris Daerah. Hal itu ditambah dengan kurangnya komitmen dari masing-masing Satuan Kerja Perangkat Daerah (SKPD) dalam mengelola aset daerah yang menjadi tanggungjawabnya. Hal ini ditegaskan oleh Kepala Bidang Akuntansi dan Pelaporan yang menyatakan bahwa:

“...kesulitan pengelolaan aset daerah diperparah dengan kurangnya komitmen dari masing-masing SKPD dalam mendukung kegiatan reinventarisasi, meskipun permasalahan ini telah menjadi perhatian dan mendapatkan warning dari Bupati agar masalah aset tetap daerah harus selesai pada akhir tahun 2012."

Hal yang sama juga disampaikan oleh pemeriksa BPK RI yang pernah melakukan pemeriksaan atas Laporan Keuangan Pemerintah Daerah Kabupaten Sampangdalam wawancara terkait dengan azas fungsional dalam pengelolaan barang milik daerah, yang menyatakan bahwa: 
“...sepertinya hampir semua kepala SKPD kurang memahami arti penting pengelolaan aset dan lebih mementingkan pengelolaan keuangan, sehingga kegiatan reinventarisasi barang milik daerah tidak berjalan optimal karena koordinasi tidak berjalan dengan baik."

b. Azas kepastian hukum, yaitu pengelolaan barang milik daerah harus dilaksanakan berdasarkan hukum dan peraturan perundang-undangan. Secara umum azas kepastian hukum telah dipenuhi Pemerintah Kabupaten Sampang dalam mengelola barang milik daerah. Menurut Kepala Bidang Akuntansi dan Pelaporandalam wawancara mengenai proses penyusunan perda maupun perbupmenyatakan:

“...untuk memastikan legalitas produk-produk perda maupun perbup, proses penyusunannya melalui dua cara, yang pertama dengan memanfaatkan jasa konsultan seperti perguruan tinggi, dan yang kedua disusun sendiri dengan mengkoordinasikan Bagian Hukum Setda dengan dinas-dinas teknis yang berkaitan dengan perda/perbup tersebut. Khusus perda akan dibahas lebih lanjut dengan legislatif untuk mendapatkan persetujuan dewan. Dengan demikian diharapkan tidak terjadi pertentangan antara perda/perbup dengan peraturan perundang-undangan di atasnya. Demikian juga dengan perda/perbup yang berkaitan dengan pengelolaan barang milik daerah. Hanya saja karena dalam pembahasannya memerlukan waktu yang lama, maka perda tentang pengelolaan barang milik daerah masih menggunakan perda yang lama."

c. Azas transparansi, yaitu penyelenggaraan pengelolaan barang milik daerah harus transparan terhadap hak masyarakat dalam memperoleh informasi yang benar. Transparansi penyelenggaraan pengelolaan barang milik daerah di Kabupaten Sampang telah diupayakan sejak proses pengadaan barang milik daerah sampai dengan proses pelaporan. Hal ini diungkapkan oleh Kepala Bidang Akuntansi dan Pelaporandalam wawancara dengan peneliti.

“...untuk menjamin transparansi dalam pengelolaan barang milik daerah kami telah mengupayakannya mulai dari proses pengadaan barang. Untuk barang-barang yg nilainya lebih dari seratus juta, dilakukan proses lelang yang diumumkan melalui electronic proquirement yang diumumkan di Bagian Pembangunan dan diupload di internet. Sedangkan untuk pelaporan berupa Laporan Keuangan yang memuat juga informasi mengenai aset tetap, diumumkan di media cetak dan diupload pada website resmi Pemerintah Kabupaten Sampang yang dapat diakses oleh masyarakat luas."

d. Azas efisiensi, yaitu pengelolaan barang milik daerah diarahkan agar barang milik daerah digunakan sesuai batasan-batasan standar kebutuhan yang diperlukan dalam rangka menunjang penyelenggaraan tugas pokok dan fungsi pemerintahan secara optimal. Azas efisiensi dalam pengelolaan barang/aset daerah pada Pemerintah Kabupaten Sampang diakui sendiri oleh Kepala Bidang Akuntansi dan Pelaporanmasih kurang, hal ini disampaikan dalam petikan wawancara berikut.

“...selama ini belum ada analisa kebutuhan barang dalam kegiatan pengadaan barang yang menjadi kebutuhan unit kerja. Kebutuhan barang mestinya dianalisa dulu oleh bagian aset untuk selanjutnya dievaluasi dan menjadi pedoman dalam pembahasan di TAPD. Jadi penganggaran barang selama ini bukan berdasarkan analisa kebutuhan, hal ini 
mengakibatkankegiatan pengadaan barang tidak diketahui apakah sudah efisien atau belum."

e. Azas akuntabilitas, yaitu setiap kegiatan pengelolaan barang milik daerah harus dapat dipertanggungjawabkan kepada rakyat. Pertanggungjawaban pengelolaan barang/aset milik daerah oleh Pemerintah Kabupaten Sampang hanya sebatas penyajian di Neraca daerah, belum sampai pada asersi keberadaan, hak dan kewajiban.Tidak semua aset tetap, terutama hasil pengadaan sebelum tahun 2008, dapat ditelusuri keberadaannya sehingga pihak yang bertanggungjawab atas hak dan kewajiban yang melekat dalam penggunaan aset tidak diketahui.Hal ini sesuai dengan pernyataan ketua tim pemeriksaan LKPD Kabupaten Sampang Tahun Anggaran 2011 dalam menanggapi akuntabilitas dalam pengelolaan barang milik daerah Kabupaten Sampang, yang menyatakan bahwa:

“...akuntabilitas aset daerah lemah karena hanya dapat dilihat dari sisi laporan keuangan saja. Akuntabilitas aset secara fisik tidak dapat diyakini karena masih banyak aset yang belum dapat ditelusuri keberadaannya."

f. Azas kepastian nilai, yaitu pengelolaan barang milik daerah harus didukung oleh adanya ketepatan jumlah dan nilai barang dalam rangka optimalisasi pemanfaatan dan pemindahtanganan barang milik daerah serta penyusunan neraca Pemerintah Daerah. Azas kepastian nilai dalam pengelolaan barang/aset milik daerah belum dapat dipenuhi oleh Pemerintah Kabupaten Sampang. Hal ini mengingat masih terdapat aset-aset daerah yang tidak dapat ditelusuri keberadaannya di samping juga adanya perbedaan pencatatan antara Bidang Akuntansi dan Pelaporan dengan Bidang Pengelolaan Aset yang mengakibatkan nilai barang/aset daerah secara keseluruhan tidak pasti.Menurut ketua tim pemeriksaan LKPD Kabupaten Sampang Tahun Anggaran 2011 dalam wawancara terkait dengan azas kepastian nilai dalam pengelolaan barang milik daerah, menyatakan bahwa:

“...azas kepastian nilai hanya dapat diukur pada pengelolaan barang mulai tahun 2009 sampai sekarang, sedangkan pengelolaan barang tahun 2009 ke belakang, nilai barang tidak pasti karena masih dalam penelusuran oleh Pemkab."

Selanjutnya, berdasarkan azas-azas pengelolaan tersebut diukur tingkat keandalan informasi aset tetap daerah Pemerintah Kabupaten Sampang dengan memperhatikan karakteristik berikut.

\section{Penyajian Jujur}

Informasi menggambarkan dengan jujur transaksi serta peristiwa lainnya yang seharusnya disajikan atau yang secara wajar dapat diharapkan untuk disajikan. Penyajian informasi pengelolaan barang/aset milik daerah yang jujur oleh Pemerintah Kabupaten Sampang berusaha dipenuhi dengan menyajikan seluruh informasi mengenai aset tetap dan permasalahannya dalam Laporan Keuangan Daerah.Menurut salah seorang pemeriksa BPK RI dalam kegiatan 
pemeriksaan LKPD Kabupaten Sampang Tahun Anggaran 2011, menyatakan bahwa:

“...penyajian informasi seputar aset tetap Kabupaten Sampang, telah diupayakan oleh pemkab dengan terbuka. Pemkab Sampang tidak berusaha menutup-nutupi permasalahan dalam pengelolaan aset, mereka mengakui adanya perbedaan pencatatan dalam pengelolaan aset daerah oleh Bidang Aset dan Bidang Akuntansi.”

Kepala Bidang Akuntansi dan Pelaporan juga menambahkan bahwa:

“...kami sudah berusaha menyajikan Laporan Keuangan apa adanya termasuk informasi mengenai aset tetap. Aset tetap kami sajikan secara riil pengeluaran, jadi selama tidak ada informasi mengenai penghapusan dari dinas-dinas terkait maka Bagian Keuangan akan menyajikan informasi aset tetap sebesar nilai riil pada saat pengadaan."

\section{Dapat Diverifikasi (verifiability)}

Informasi yang disajikan dalam laporan keuangan dapat diuji, dan apabila pengujian dilakukan lebih dari sekali oleh pihak yang berbeda hasilnya tetap menunjukkan simpulan yang tidak berbeda jauh. Karakteristik keandalan informasi ini juga belum dapat terpenuhi oleh Pemerintah Kabupaten Sampang mengingat bahwa saldo aset tetap daerah tidak dapat diuji keberadaannya.

“...data aset sulit diverifikasi karena secara keberadaan belum diketahui. Hal ini ditambah lagi dengan adanya perbedaan pengkodean barang yang mengakibatkan keberadaan sejumlah aset tidak diketahui."

\section{Netralitas}

Informasi diarahkan pada kebutuhan umum dan tidak berpihak pada kebutuhan pihak tertentu. Pengelolaan barang/aset milik daerah oleh Pemerintah Kabupaten Sampang dilaksanakan dengan mempertimbangkan kebutuhan umum dan tidak berpihak pada kebutuhan pihak tertentu hal ini ditegaskan oleh Kepala Bidang Akuntansi dan Pelaporan yang menyatakan bahwa:

“....informasi aset tetap dalam neraca daerah telah disampaikan apa adanya dan tidak ada kepentingan tertentu yang melatarbelakangi penyusunan laporan tersebut."

\section{Permasalahan yang dihadapi pemerintah daerah dalam pelaksanaan SAP berbasis akrual berkaitan dengan aset tetap daerah}

Berdasarkan penelitian atas pengelolaan barang/aset daerah pada Pemerintah Kabupaten Sampang tersebut diketahui hal-hal sebagai berikut. 
a. Secara umum, masih banyak Pengguna Barang (Kepala Dinas/Badan) yang belum memahami pentingnya pengelolaan barang milik daerah, terutama aset tetap daerah.

b. Rekonsiliasi antara Bidang Akuntansi dan Pelaporan dengan Bidang Pengelolaan Aset belum tuntas, sehingga masih terdapat perbedaan dalam pencatatan besarnya aset tetap daerah.

c. Kebijakan akuntansi mengenai penyusutan aset tetap belum ada, sehingga pencatatan akrual terkait biaya penyusutan belum dapat dilaksanakan.

d. Rincian aset tetap daerah per jenis barang belum ada sehingga pengurus barang akan mengalami kesulitan dalam penerapannya apabila kebijakan akuntansi mengenai penyusutan aset tetap telah diterbitkan.

e. Pemahaman SDM yang terlibat dalam pengelolaan aset tetap masih kurang.

Untuk menjalankan program standar akuntansi pemerintah terhadap aset tetap dengan baik, ada beberapa hal yang harus segera dilakukan pembenahan oleh Pemerintah Kabupaten Sampang yaitu:

a. Meningkatkan koordinasi dalam pengelolaan aset tetap daerah.

b. Melakukan inventarisasi atas aset yang dimiliki tiap unit pemerintah.

c. Menertibkan pencatatan aset tetap untuk menjamin keakuratan data.

d. Menerapkan akuntansi aset untuk mendukung penyusunan neraca dan pengelolaan aset.

e. Meningkatkan kualitas SDM yang menangani aset tetap.

\section{SIMPULAN}

Dari penelitian yang dilakukan, beberapa hal yang menjadi simpulan adalah sebagai berikut.Pengelolaan Barang/aset Milik daerah pada Kabupaten Sampang belum dilaksanakan secara memadai.Berdasarkan penerapan azas-azas dalam pengelolaan barang/aset milik daerah dan selanjutnya dikaitkan dengan karakteristik keandalan informasi, maka dapat disimpulkan bahwa penyajian informasi aset tetap daerah pada Pemerintah Kabupaten Sampang belum andal.

Berdasarkan penelitaian atas pengelolaan barang/aset daerah pada Pemerintah Kabupaten Sampang tersebut diketahui hal-hal: (1) Secara umum, masih banyak Pengguna Barang (Kepala Dinas/Badan) yang belum memahami pentingnya pengelolaan barang milik daerah, terutama aset tetap daerah, (2) Rekonsiliasi antara Bidang Akuntansi dan Pelaporan dengan Bidang Pengelolaan Aset belum tuntas, sehingga masih terdapat perbedaan dalam pencatatan besarnya aset tetap daerah, (3) Kebijakan akuntansi mengenai penyusutan aset tetap belum 
ada, sehingga pencatatan akrual terkait biaya penyusutan belum dapat dilaksanakan, (4) Rincian aset tetap daerah per jenis barang belum ada sehingga pengurus barang akan mengalami kesulitan dalam penerapannya apabila kebijakan akuntansi mengenai penyusutan aset tetap telah diterbitkan, (5) Pemahaman SDM yang terlibat dalam pengelolaan aset tetap masih kurang.

\section{DAFTAR PUSTAKA}

Akram, Muhammad. 2011. http://asetdaerah.blogspot.com/2011/10/akuntansiaset-tetap.html

Akram, Muhammad. 2011. http://asetdaerah.blogspot.com/2011/10/definisi-asettetap-dan-barang.html

BPKP, 2002. Modul Pelatihan Dasar-Dasar Akuntansi 1. Jakarta: Badan Pengawasan Keuangan dan Pembangunan.

Harahap, Sofyan Syafri. Teori Akuntansi, Edisi Revisi, Jakarta, PT RajaGrafindo Persada, 2007.

http://jo-johan.blogspot.com/2010/03/telaah-reformasi-akuntansi-pemerintahan. html, Telaah Reformasi Akuntansi Pemerintahan (Menuju Basis Akrual) Dalam Mewujudkan Good Governance, Kamis, 18 Maret 2010.

Ikatan Akuntan Indonesia, Penerapan Akuntansi Berbasis Akrual dalam Sistem Akuntansi Pemerintah dan Sektor Publik.

Komite Standar Akuntansi Pemerintahan, Buletin Teknis Standar Akuntansi Pemerintahan Nomor 09, Akuntansi Aset Tetap, Jakarta, 2005.

Mulyana, Budi. Penggunaan Akuntansi Akrual Di Negara-Negara Lain: Tren Di Negara-Negara Anggota OECD.

Peraturan Dalam Negeri Nomor 17 Tahun 2007 tentang Pedoman Teknis Pengelolaan Barang Milik Daerah.

Peraturan Pemerintah Nomor 71 Tahun 2010 tentang Standar Akuntansi Pemerintahan.

Pratama, Arie. 2007. Analisis Faktor-Faktor Yang Menyulitkan Penerapan Akuntansi Akrual dan Pengaruhnya Terhadap Kualitas Informasi Akuntansi Di Pemerintahan Indonesia, Skripsi, Universitas Diponegoro, Semarang. 
Simanjuntak, Binsar.H. 2005. Menyongsong Era Baru Akuntansi Pemerintahan di Indonesia. Jurnal Akuntansi Pemerintahan Vol.1 No.1, Mei.

Simanjuntak, Binsar.H. 2010.Penerapan Akuntansi Berbasis Akrual Di Sektor Pemerintahan Di Indonesia disampaikan Pada Kongres XI Ikatan Akuntansi Indonesia, Jakarta, 9 Desember.

Sirait, Goklas, 2007. http://goklassirait.blogspot.com/2007/07/penyajian-asettetap-dalam-neraca.html, Penyajian Aset Tetap dalam Neraca Pemerintah, Minggu, 8 Juli 2007.

Peraturan Bupati Nomor 26 Tahun 2009 tentang Kebijakan Akuntansi Kabupaten Sampang, 4 Agustus 2009. 